\title{
VARIATION OF THE FORCES WITH THE WIND DIRECTION TO AN EXPERIMENTAL MODEL OF AERODYNAMIC PROFILE OF WIND TURBINE
}

\author{
Nelu CAZACU \\ "Dunarea de Jos" University of Galati, Romania \\ e-mail: nelu.cazacu@ugal.ro
}

\begin{abstract}
The work is based on wind tunnel experiments on an experimental turbine blade model. The vertical force (Lift) and the resisting force (Drag, in the wind direction) are measured. The tests can be considered under static conditions because the experimental model rotates with a hexadecimal degree per second. The measurement range is $180(-90 \ldots+90)$ at the maximum wind speed of $9 \mathrm{~m} / \mathrm{s}$. The results confirm the importance of the position of the blade with respect to the wind direction and its speed.
\end{abstract}

KEYWORDS: wind tunnel, lift force, drag force

\section{Introduction}

The phenomenological understanding of lift (lift), drag force (drag), aerodynamic fineness of the profile and the influence of the angle of attack on the behaviour of the aerodynamic profile, is the basis for designing small wind turbines. The aerodynamic profile is the cross section through a wind turbine such as the NACA 4412 profile is shown in Fig. 1 [1]. Under certain conditions of air flow in addition to this profile, the load-bearing force appears in the blade and which is large enough to generate a couple of forces.

The wind blades have similar aerodynamic profiles, because the working principle is the same as in the wing of the plane, the resultant being the carrying force and the resistant force. This time the air mass is naturally moving in the form of air currents (wind) that are generated by the pressure differences between two geographical points at different distances. Mainly the local pressure at these points is given by the density of the air (atmosphere) the hot air having a lower density than the cold air.

Much of the energy of radiation from the sun is found in the kinetic energy of the wind $[2,3]$.

A specialized profile for the three-blade wind turbine downstream is SG6050 (Selig / Giguere), where the name retains the inventors' initials.

Aerodynamic profiles are still considered to be a combination of art and science. Profiles are constructed by coordinates $(\mathrm{x}, \mathrm{y})$ for a large number of points). Performance verification is usually done under laboratory conditions, based on experiments in the wind tunnel on experimental models, after which the main curves characterizing the behaviour of the profile are constructed.

Small wind turbines occupy an important area in wind energy conversion like night lighting. A common application of such wind turbines is to illuminate the parking spaces at night [4]. This application is widespread and due to the development of white LEDs that have very low consumption compared to lighting methods considered classic for such applications the small wind turbines must be adapted to the annual wind values in the location area and equipped with a DC or AC multiplier and electric generator.

In both generator situations the voltage and DC current used to charge a battery (battery) are obtained by intercalating some converters. For example, you can use a DC: DC converter that has a large input range and $12 \mathrm{~V}$, or $24 \mathrm{~V}$ or $48 \mathrm{~V}$ at the output. The diameter of small residential wind turbines has values between $1 \ldots 2.5 \mathrm{~m}$, the number of blades is $2 \ldots 6$, the output power being $300 \mathrm{~W} \ldots .2 .5 \mathrm{~kW}$, for low wind speeds, the method of widening the blade is used by increasing the gas-dynamic length of the profile. A reduction of the wind speed by half can be associated with a two-fold increase in the airflow length, to maintain the same Re. 

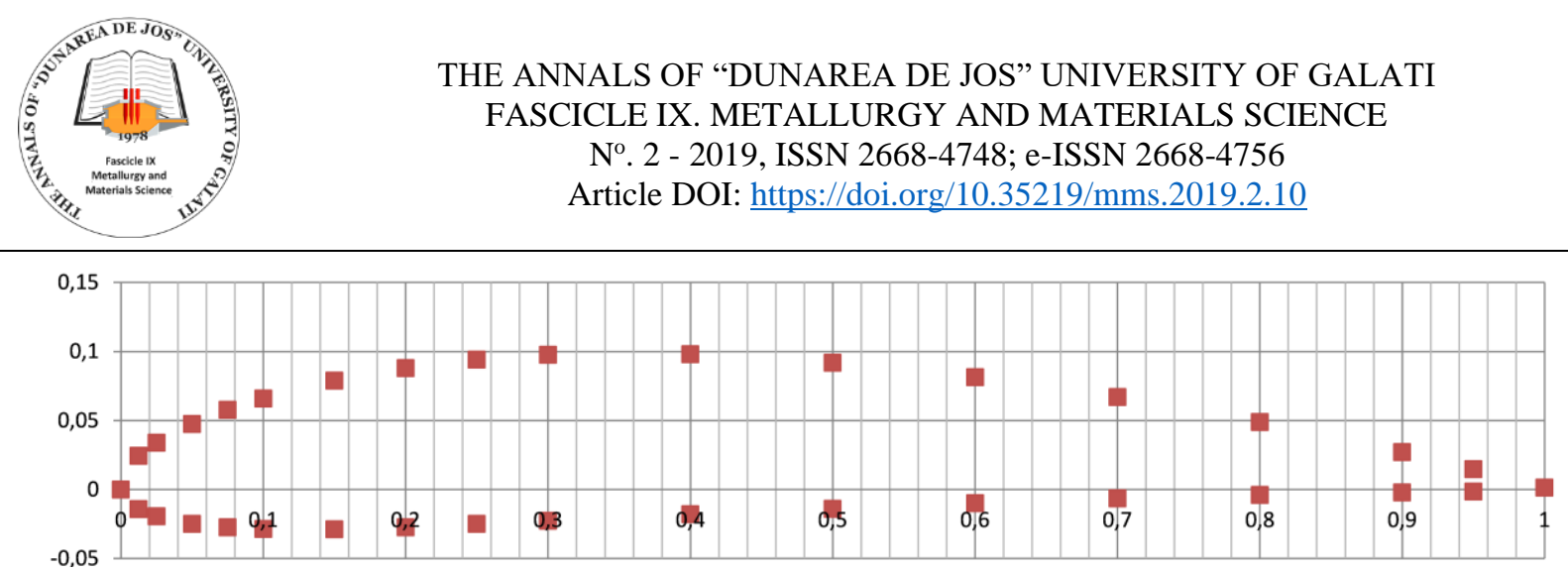

Fig. 1. NACA4412 airfoil [1]

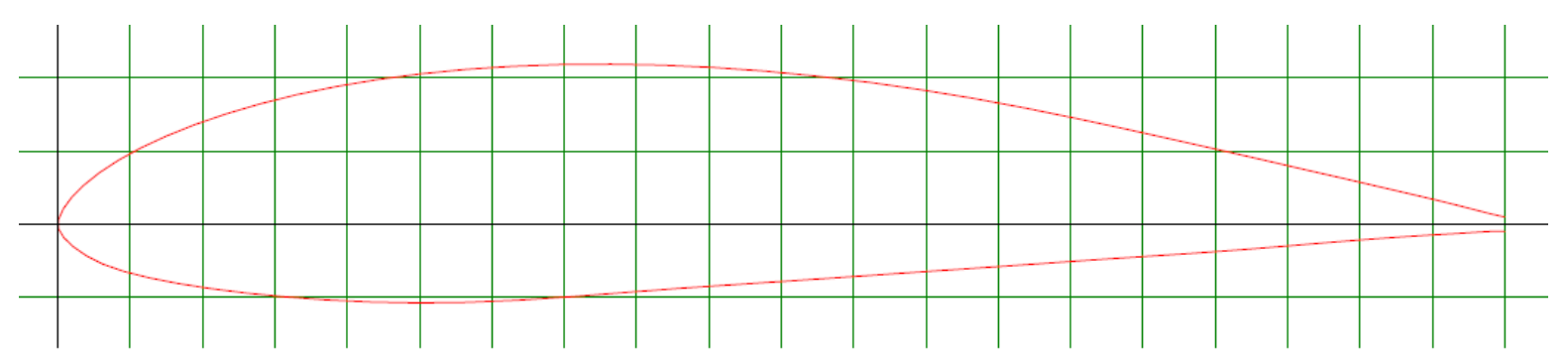

Fig. 2. SG6050 (Selig/Giguere) airfoil for HAWT blade [1]

\section{Experimental conditions}

The use of aerodynamic profiles (airfoil) when making blades for small wind turbines with three blades (upstream, turbine before the tower), is based on their special behaviour, respectively the lift force and drag force with an $\mathrm{L} / \mathrm{D}$ ratio as high as possible [5].

An air-dynamic profile was used for which the angle of the chord of the profile with the wind direction from -90 to $+90^{\circ}$ was changed, $\mathrm{L}$ and $\mathrm{D}$ are measured with sensors and plotted $\mathrm{L}$ and $\mathrm{D}$ for different positioning angles.

Abbreviations:

NACA - National Advisory Committee for Aeronautics (SUA)

UIUC - University of Illinois at Urbana-Champaign, (SUA)

NREL - National Renewable Energy Laboratory (SUA)

Notations:

$v$ - wind speed, $\mathrm{m} / \mathrm{s}$;

$v_{a}$ - apparent wind speed, $\mathrm{m} / \mathrm{s}$;

$v_{\text {tip }}$ - tip speed of blade, $\mathrm{m} / \mathrm{s}$;

A - aria, $\mathrm{m}^{2}$;

$\alpha$ - angle of attack, ${ }^{\circ}$;

$\varphi$ - apparent wind angle with turbine plane, (base disk), ${ }^{\circ}$;

$\beta$ - pitch angle of blade, ${ }^{\circ}$;

$L$ - Lift force, $N$;

$D$ - Drag force, $N$;
$T$ - Thrust force, $N$;

$D V$ - Driving Force, $N$;

$k$ - quality airfoil coefficient

Re - Reynolds number, ad;

An experimental model (EM) is used in the form of an area of a wind turbine blade [3]. The experimental model is showed in Fig. 2 and has the following characteristics: blade length: $0.158 \mathrm{~m}$, blade width: $0.158 \mathrm{~m}$, maximum thickness: $0.030 \mathrm{~m}$, chord: 0.158 , length on intrados: $0.164 \mathrm{~m}$, length on extrados $0.172 \mathrm{~m}$ : chord/ high ratio: 5.26.

For experiments we used: wind tunnel with maximum wind speed of $9 \mathrm{~m} / \mathrm{s}$, and measurement section of $0.5 \mathrm{~m} \times 0.5 \mathrm{~m} \times 1.25 \mathrm{~m}$, anemometer LCA6000, balance for measuring forces at two points (with measuring cell and film resistors). The experimental measurement system also contains the following elements: SAD Arduino UNO, anemometer $\left(2^{\text {nd }}\right)$, force cell type sensors for $\mathrm{L}$ and $\mathrm{D}, \mathrm{A} / \mathrm{N}$ converters with HC711, Futaba S3003 servomotor, program (code).

For experiments we have two independent variables: the wind speed and the positioning angle of the model. The dependent variables are: the lift force, the drag force [3]. The choice of model testing at different fixed wind speeds was chosen: $0 \mathrm{~m} / \mathrm{s}, 3 \mathrm{~m} / \mathrm{s}$, $5 \mathrm{~m} / \mathrm{s}$ and $9 \mathrm{~m} / \mathrm{s}$. For each of these, a graph showing the variation $L$ and $D$ with the rotating angle of the model is recorded (the angle of placement of the blade). The actuator rotates by $1 \% \mathrm{~s}$ and therefore it is considered static determinations. 

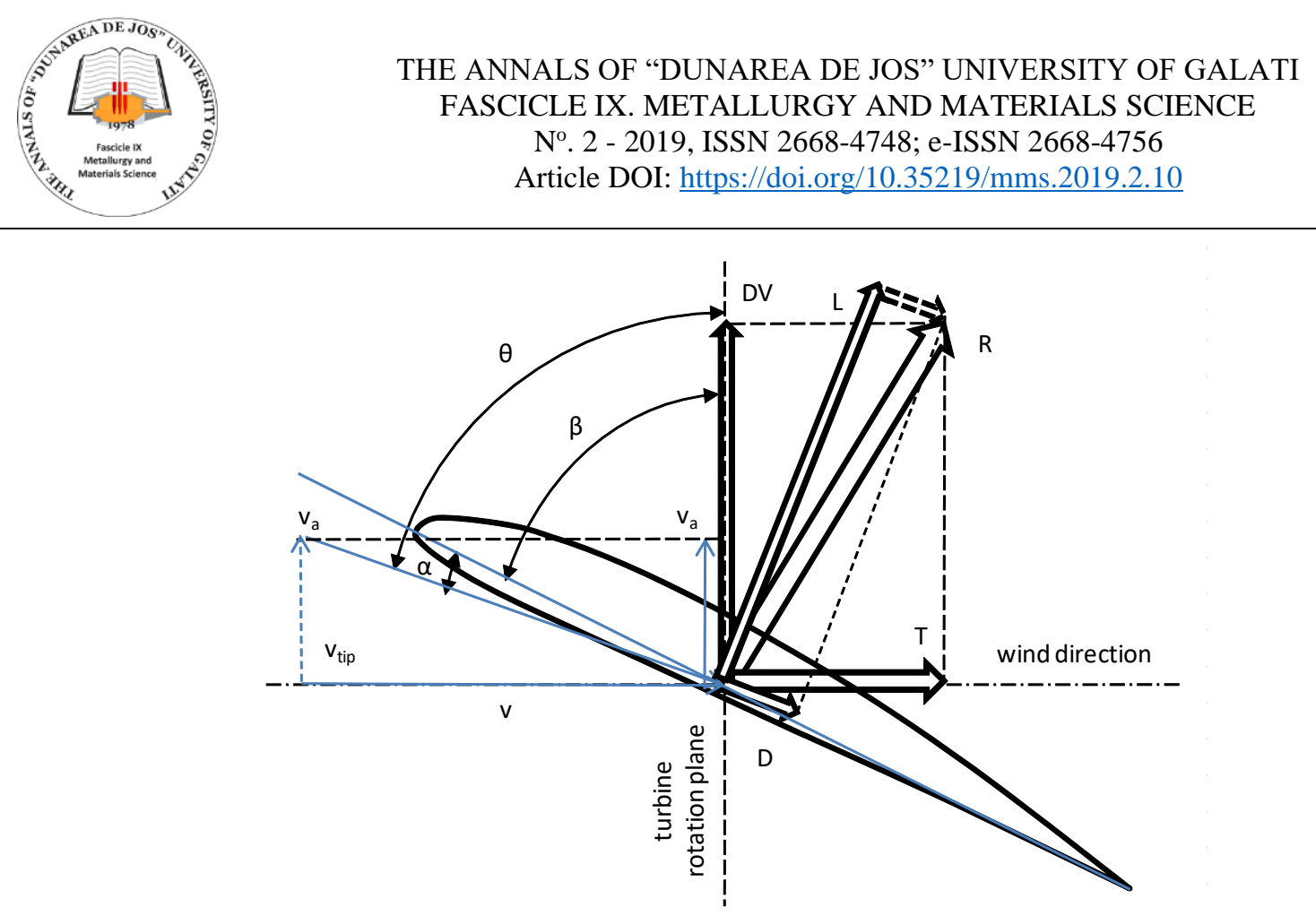

Fig. 3. Principle diagram of the arrangement of velocity and force vectors for a three-blade wind turbine [2]

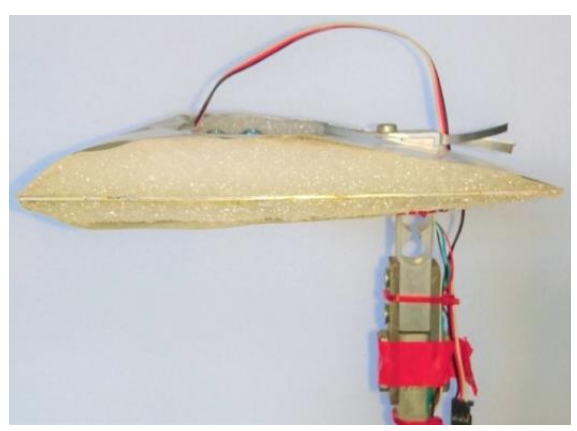

Fig. 4. Experimental model at $0^{\circ}$ angle

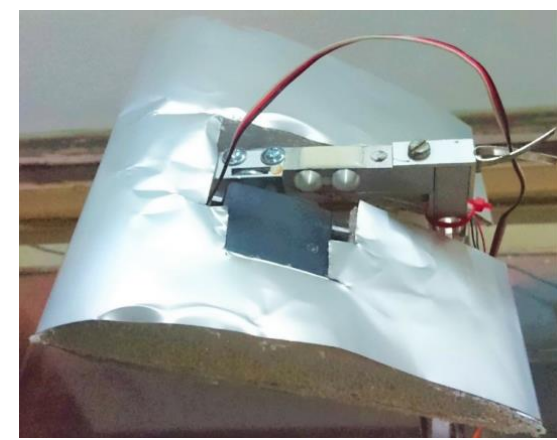

Fig. 5. Experimental model in attack angle $0 . . .15^{\circ}$

\section{Results and discussion}

The variation $\mathrm{L}$ and $\mathrm{D}$ is tracked with the wind speed and for different values of the angle of attack. For this, for each wind speed $(0 \mathrm{~m} / \mathrm{s}, 3 \mathrm{~m} / \mathrm{s}, 5 \mathrm{~m} / \mathrm{s}$ and $9 \mathrm{~m} / \mathrm{s}$ ) a graph is recorded on the interval $-90^{\circ} \ldots+90^{\circ}$. Below we analyse each graph. For the speed $0 \mathrm{~m} / \mathrm{s}$ of the wind a variation of $\mathrm{L}$ and $\mathrm{D}$ caused by the change of the model's position with respect to the axis of rotation is observed, given that the axis of rotation is not exactly in the mass center.

The force is between $-0.3 \ldots+0.5 \mathrm{~N}$ At speed $\mathrm{v}=$ $3 \mathrm{~m} / \mathrm{s}$ it is found that $\mathrm{L}$ and $\mathrm{D}$ have distinct variations depending on the position of the blade, both have an approximately sinusoidal appearance with a phase gap between them. $\mathrm{D}$ is maximum at 0 degrees and 180 degrees on the graph which corresponds to the angles of $-90^{\circ}$ and $+90^{\circ}$. The force $\mathrm{L}$ has a special variation in the sense that at $-90^{\circ}$ it has a small negative value $(1 \mathrm{~N})$ and then it increases to about +3 $\mathrm{N}$. In this interval, the favourable angle of attack is also taken $5 \ldots 15^{\circ}$, at the maximum value the area also showing a vortex variation. $\mathrm{L} / \mathrm{D}=3$ (in absolute values).

At $v=5 \mathrm{~m} / \mathrm{s}$ the curves $\mathrm{L}$ and $\mathrm{D}$ have the same allure on $180^{\circ}$ range of variation. The values and slopes of the curves are changed. $\mathrm{L}$ has the maximum value $2 \mathrm{~N}$ and at the same value $\mathrm{D}=-4 \mathrm{~N}$. The $\mathrm{L} / \mathrm{D}$ ratio becomes small and its value is approx. 0.5. This shows a reduced fineness of the experimental model. $\mathrm{D}$ reaches $-4 \mathrm{~N}$ at about $90^{\circ}$. The positioning of the sensors makes the measured sheets not pure forces. For example, sensor D also adds a torque when the angle is different from zero. An exact calculation introduces corrections that take into account the true composition of forces and moments.

The behaviour of the model at $\mathrm{v}=9 \mathrm{~m} / \mathrm{s}$. This is the maximum speed that the wind tunnel can develop. $\mathrm{L}$ reaches maximum $7 \mathrm{~N}$ at $\mathrm{D}=10 \mathrm{~N}$. That is $\mathrm{L} / \mathrm{D}=$ 0.7 which shows a poor aerodynamic profile. Usual $\mathrm{L}$ $/ \mathrm{D}=5 \ldots 10$. When rotating from $90^{\circ}$ to $0^{\circ} \mathrm{L}$ it increases and $\mathrm{D}$ is almost constant, around zero. 
THE ANNALS OF “DUNAREA DE JOS” UNIVERSITY OF GALATI

FASCICLE IX. METALLURGY AND MATERIALS SCIENCE

No. 2 - 2019, ISSN 2668-4748; e-ISSN 2668-4756

Article DOI: $\underline{\text { https://doi.org/10.35219/mms.2019.2.10 }}$

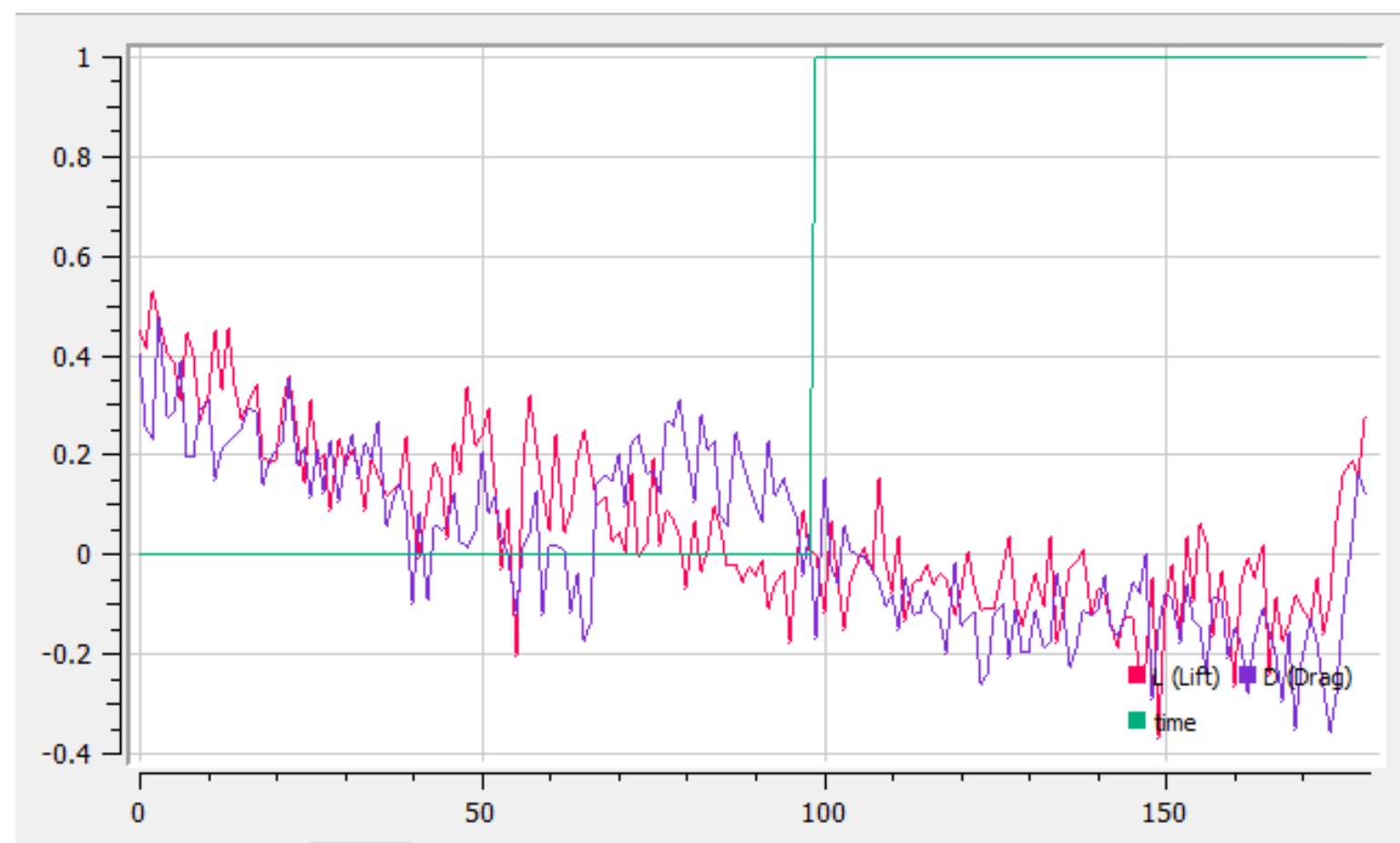

Fig. 6. Variation of forces L and $D$ (measured in $N)$ at a cycle of $180^{\circ}\left(-90^{\circ} \ldots+90^{\circ}\right)$, without wind

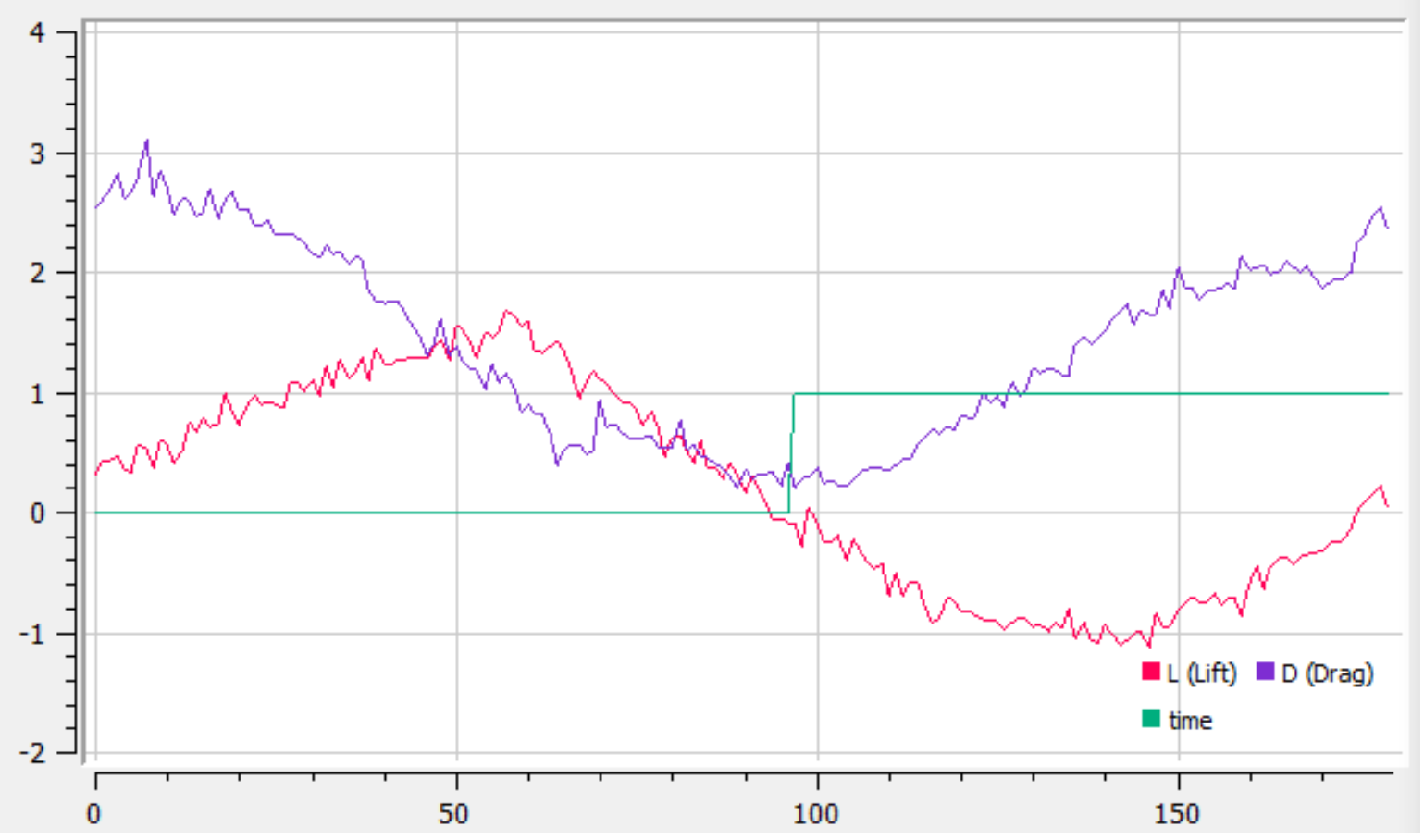

Fig. 7. Variation of forces $L$ and $D$ (measured in $N)$ at a cycle of $180^{\circ}\left(-90^{\circ} \ldots+90^{\circ}\right)$, for the wind speed of $3 \mathrm{~m} / \mathrm{s}$ 

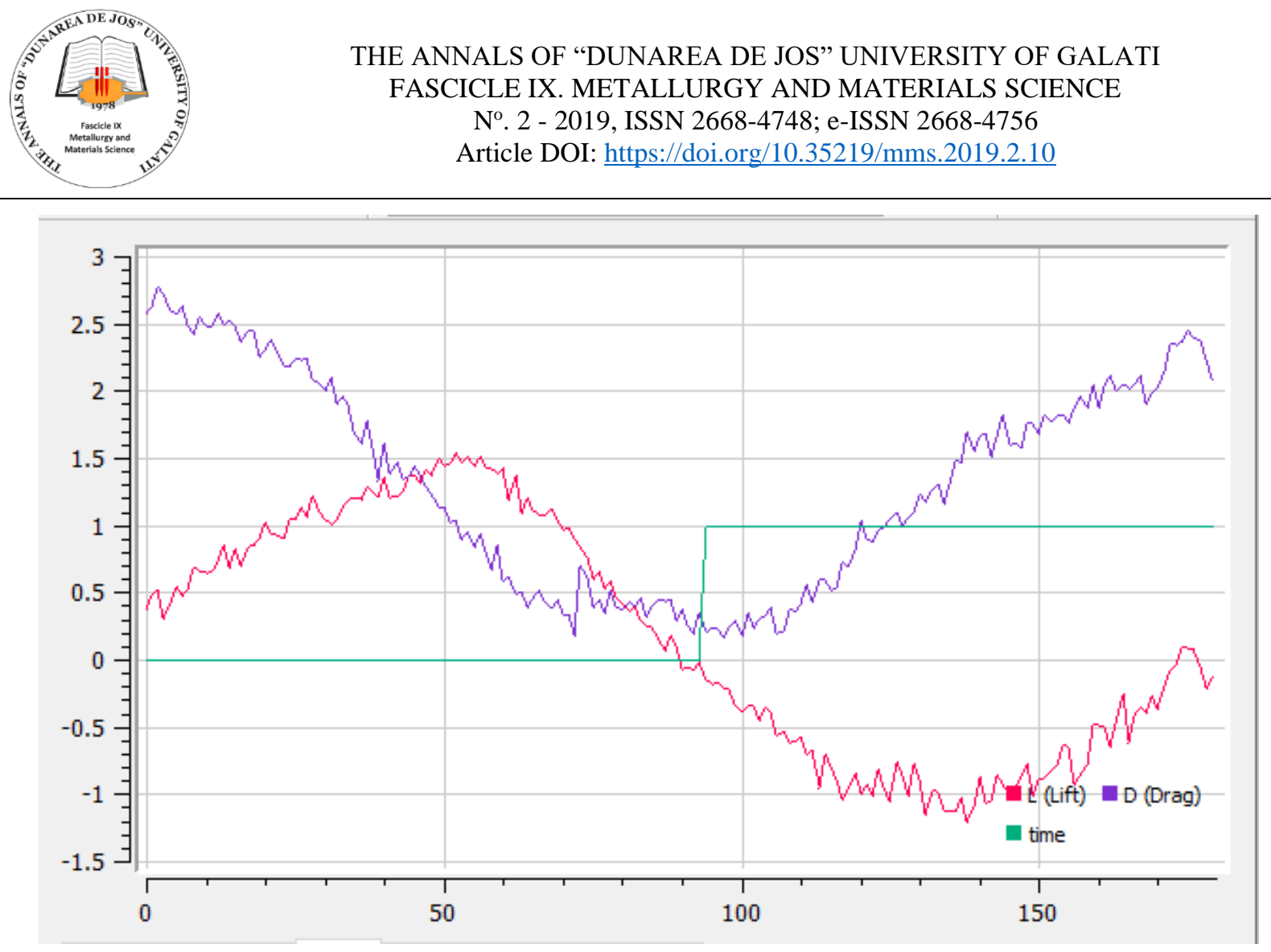

Fig. 8. Variation of forces $L$ and $D$ (measured in $N$ ) at a cycle of $180^{\circ}\left(-90^{\circ} \ldots+90^{\circ}\right)$, at a wind of $5 \mathrm{~m} / \mathrm{s}$

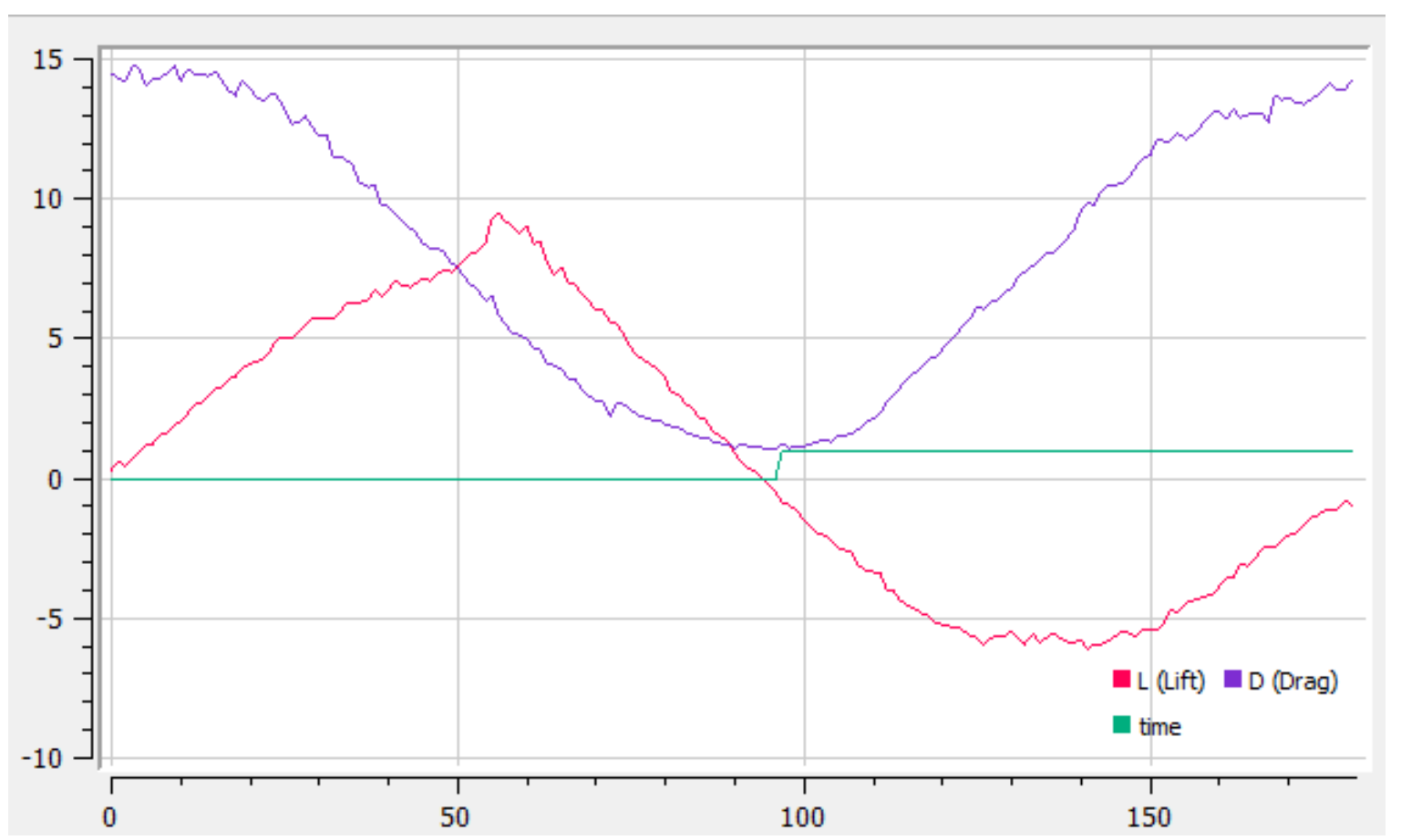

Fig. 9. Variation of forces $L$ and $D$ (measured in $N)$ at a cycle of $180^{\circ}\left(-90^{\circ} \ldots+90^{\circ}\right)$, at a wind of $9 \mathrm{~m} / \mathrm{s}$

This shows that the resisting force overrides the mass of the model. Then at $90^{\circ}$ a maximum of resistance and a minimum of lift is reached.

\section{Conclusions}

According to the figures Fig. 6...Fig. 9 analysed above, the proposed airfoil has a good behaviour at 


\section{THE ANNALS OF "DUNAREA DE JOS" UNIVERSITY OF GALATI \\ FASCICLE IX. METALLURGY AND MATERIALS SCIENCE \\ No. 2 - 2019, ISSN 2668-4748; e-ISSN 2668-4756 \\ Article DOI: https://doi.org/10.35219/mms.2019.2.10}

high wind speeds $(9 \mathrm{~m} / \mathrm{s})$ for which it has an attack angle range of approx. 40 degrees.

The axis of rotation must be placed in the center of mass of the experimental model to reduce errors (Fig. 6).

The quality coefficient of the L / D profile is 3 to $3 \mathrm{~m} / \mathrm{s}$ (maximum value).

The lift force has a maximum value of $10 \mathrm{~N}$ at $9 \mathrm{~m} / \mathrm{s}$ and the values of the drag force increase with the speed, $t$ and reach a maximum of $15 \mathrm{~N}$. When the profile is placed with the chord in the wind direction the drag force had minimum values for all experiments with wind speed greatest than zero.

\section{References}

[1]. ****, http://airfoiltools.com/airfoil/details?airfoil=naca4412ilAirfoil Tools.

[2]. Dumitrescu H., Georgescu A., Calcului elicei, Cap.4 Elicea eoliana, s.l.: Editura Academiei Romane, 1990.

[3]. Selig Michael S., McGrahan Brian D., Wind Tunnel Aerodynamic Tests of Six Airfoils for Use on Small Wind Turbines, Urbana, Illinois: NREL, vol. NREL/SR-500-34515, 2004.

[4]. Hau Erich, Wind Turbines, Fundamentals, Technologies, Applications, Economics, s.l.: Springler, 2006.

[5]. Smulders P. T., Rotors for wind power, Eindhoven: University of Technology, Eindhoven, Faculty of Physics, 1st edition October 1991, (revised edition January 2004).

[6]. Manwell J. V., McGowan J. G., Rogers A. L., Wind Energy Explained. Theory, Design and Application.

[7]. Mathew Sathyajith, Wind Energy_Fundamentals, Resource Analysis and Economics, s.1.: Springer, 2006. 